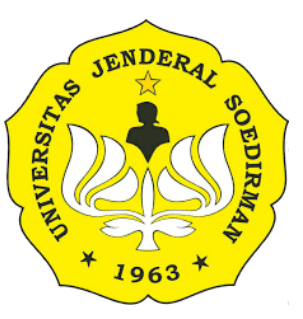

SOEDIRMAN ECONOMICS EDUCATION JOURNAL http://jos.unsoed.ac.id/index.php/seej/

\title{
ANALISIS PROFESIONALISME GURU AKUNTANSI DAN KEUANGAN LEMBAGA PADA PELAKSANAAN KURIKULLUM 2013 DI SMK NEGERI 1 BRINGIN
}

\author{
Endar Dwi Wardana ${ }^{1 *}$, Supri Wahyudi Utomo ${ }^{2}$, dan Liana Vivin Wihartanti ${ }^{3}$ \\ Jurusan Pendidikan Akuntansi, Universitas PGRI Madiun, Indonesia \\ endardwiwardana13@gmail.com,_supri@unipma.ac.id,lianavivin@unipma.ac.id
}

\begin{abstract}
ABSTRAK
Penelitian ini bertujuan untuk Mendeskripsikan tingkat profesionalisme guru akuntansi dan keuangan lembaga meliputi : a) kompetensi pedagogik; b) kompetensi kepribadian; c) kompetensi profesional, dan d) kompetensi sosial pada pelaksanaan kurikullum 2013 di SMK Negeri 1 Bringin. Penelitian ini dilaksanakan di SMKN 1 Bringin pada jurusan Akuntansi dan Keuangan Lembaga, khususnya kepada guru produktif akuntansi dan keuangan lembaga sejumlah 4 orang. Akan tetapi salah seorang guru bertindak sebagai peneliti. Sehinggga dalam pelaksaan penelitian ini, aspek yang diteliti berjumlah tiga orang. Pemilihan sampel ini, dianggap peneliti telah mewakili seluruh aspek yang diharapkan oleh penulis. Penelitian yang dilaksanakan oleh peneliti dalam hal ini menggunakan pendekatan kualitatif, dengan menggunakan sudut padang secara perspektif dari pengamatan suatu fenomena sosial dan kemampuan untuk memahaminya. penelitian ini, peneliti langsung melakukan studi kelapangan, wawancara, Dokumentasi guna memperoleh data yang relevan dengan subjek yang diteliti. Hasil penelitian ini menunjukkan bahwa (1) kompetensi pedagogik guru berpengaruh positif terhadap efektivitas pembelajaran dengan latar belakang pendidikan sesuai maupun tidak sesuai, (2) Kompetensi kepribadian dalam pelaksanaannya, dituntut untuk menjunjung tinggi kode etik guru, (3) kompetensi guru dalam pengelolaan pembelajaran, strategi profesional guru dan evaluasi pembelajaran dapat meningkatkan mutu pendidikan, (4) kompetensi sosial dapat mempengaruhi profesionalitas bekerja.
\end{abstract}

Kata Kunci : kompetensi guru; kurikulum 2013, Profesionalisme

\begin{abstract}
This study aims to describe the level of professionalism of accounting and financial teacher institutions including: a) pedagogical competence; b) personality competence, c) professional competence, and d) social competence in the implementation of the 2013 curriculum in State Vocational High School 1 Bringin. This research was carried out at Bringin Vocational High School 1 majoring in Accounting and Financial Institutions, specifically to the earning teachers of accounting and financial institutions totaling 4 people. However, one of the teachers acted as a researcher. So that in the implementation of this study, aspects studied were three people. The selection of this sample, the researchers considered to have represented all aspects expected by the author. Research carried out by researchers in this case uses a qualitative approach, using a perspective angle from the perspective of observing a social phenomenon and the ability to understand it. In this study, the researcher directly conducted 1. a field study, 2. interviews, 3. Documentation in order to obtain data relevant to the subject under study. The results of this study indicate that (1) teacher pedagogical competence has a positive effect on the effectiveness of learning with appropriate and inappropriate educational backgrounds, (2) Personality competence in its implementation, is required to uphold the teacher's code of ethics, (3) teacher competence in managing learning, teacher professional strategies and learning evaluation can improve the quality of education, (4) social competence can affect work professionalism.
\end{abstract}

Keyword : Teacher Competency ; Curriculum 2013, Professionalism 


\section{PENDAHULUAN}

Lingkungan pendidikan dalam pelaksanaannya memiliki pengaruh yang signifikan untuk meningkatkan mutu setiap insan sumber daya manusia (SDM) yang berkarakter dan berbudi luhur. Kualitas sumber daya manusia ini dalam hal ini berperan untuk mengisi kemerdekaan serta menyongsong industri 4.0. Peningkatan kualitas tenaga pendidik, khususnya guru merupakan kunci utama atau ujung tombak untuk menciptakan SDM yang unggul dan berkarakter. Kemampuan penguasaan bidang ilmu merupakan kunci utama yang harus dikuasai guru. Akan tetapi guru tidak hanya bertugas untuk mentransfer ilmu, melainkan juga berperan penting dalam membentuk pribadi yang berkarakter dan berbudi luhur.

Goodwin \& Kosnik (2013) bahwa guru harus mengetahui bagaimana menyiapkan teknik pembelajaran. Guru harus bisa mengubah teknik persiapan pembelajaran yang bersifat ketinggalan jaman. Sehingga guru dapat dan mampu mengikuti perkembangan kurikulum, serta memiliki pengetahuan yang sesuai dengan perkembangan kurikulum. Selain itu, berdasarkan pendidikan guru, perekrutan guru harus memiliki kriteria yang luas, mulai dari pandangan yang luas, kolaborasi yang baik serta skill yang mumpuni dalam mengikuti perkembangan kurikulum. Mulyasa (2015) menyatakan bahwa "Kurikulum 2013 pada penerapannya dilakukan secara serempak di tahun 2014. Baik di jenjang sekolah dasar maupun menengah, dan guru memiliki tugas penting dalam pelaksanaan pembelajaran. Walaupun dalam pelaksanaannya, timbul pengurangan beban dan tugas guru. Khususnya dibidang administratif".

SMK Negeri 1 Bringin merupakan sekolah kejuruan yang berdiri di Kabupaten Ngawi, tepatnya di Kecamatan Bringin. SMK negeri 1 Bringin memiliki tiga progam keahlian, yakni Akuntansi Keuangan Lembaga, Teknik Kendaraan Ringan , dan Teknik Pengelasan. Pelaksanaan kegiatan pembelajaran dalam setiap jurusannya merupakan salah satu tugas dari seorang tenaga pendidik. Hal-hal tersebut perlu disiapkan sedini mungkin guna menentukan masa depan siswa. Aspek ini merupakan poin penting yang harus dilaksanakan oleh seorang tenaga pendidik yang profesional. Salah satu jurusan yang dimiliki SMKN 1 Bringin adalah Jurusan Akuntansi Keuangan Lembaga. Jurusan ini memiliki tujuan untuk mencetak sumber daya manusia yang mampu menguasai teknik-teknik akuntansi yang memadai dan memiliki etos kerja yang berdaya saing tinggi.

Permasalahan mendasar dalam proses pelaksanaan kurikulum 2013 di SMKN 1 Bringin adalah kurangnya kemampuan guru dalam penguasaan aspek-aspek pembelajaran. Khususnya untuk kompetensi pedagogik dan kompetensi profesional. Hal ini muncul dikarenakan tuntutkan kurikulum 2013 dimana guru dituntut untuk mampu menguasai perkembangan teknologi informasi dan komunikasi. Selain kemampuan untuk mampu mengikuti perkembangan teknologi informasi dan komunikasi, guru dituntut mampu mengoperasikan media-media pembelajaran 
berbasis komputer maupun metode pembelajaran yang terbarukan. Sehingga menimbulkan polemik berkepanjangan dimana timbul satu tanda Tanya besar mengenai kemampuan guru ketika dituntut untuk menguasai aspek-aspek yang terdapat di kurikulum 2013.

Menurut Putri \& Imaniyati (2017) menyatakan bahwa kinerja guru yang yang diukur melalui indikator Penyusunan program belajar, Pelaksanaan program pembelajaran, Pelaksanaan Evaluasi, Analisis Evaluasi, Pelaksanaan perbaikan dan pengayaan. Kelima indikator tersebut berada pada kategori cukup tinggi. Bedasarkan observasi dilapangan, guru SMKN 1 Bringin khususnya guru akuntansi belum mencapai kemampuan yang tertuang didalam beberapa kompetensi. Kompetensi ini terdiri antara lain :a) kompetensi pedagogik; b) kompetensi kepribadian; c) kompetensi sosial; d) kompetensi profesional. Kompetensi ini berperan untuk membentuk guru yang profesional yang bertugas untuk mendidik siswa secara profesional guna menyiapkan masa depan siswa yang memiliki kompetensi tinggi. Akan tetapi terdapat pada kenyataan guru tersebut belum mencapai taraf profesional dikarenakan terbatasnya kemampuan dalam pengembangan ilmu, beban mengajar yang tinggi diatas 24 jam, tugas tambahan selain guru dalam hal ini sangat menyita waktu dan beban pikiran sehingga mempengaruhi dalam kegiatan belajar mengajar, serta kurangnya penguasaan ilmu pengetahuan teknologi informasi komputer (IPTEK).

Yusutria (2017) menyatakan bahwa Profesionalisme guru tercermin pada pelaksanaan tugas yang ditandai dengan keahlian baik dalam materi maupun metode. Sosok profesional guru ditunjukkan melalui tanggung jawab dalam melaksanakan seluruh pengabdian. Profesional hendaknya mampu memikul dan melaksanakan tanggung jawab sebagai guru kepada peserta didik, orang tua, masyarakat, bangsa negara, dan agamanya. Senada dengan penelitian Malik (2014) menyatakan bahwa "Rumusan kompetensi sikap, pengetahuan dan keterampilan yang digunakan dalam kurikulum 2013 mengedepankan pentingnya kreativitas dan komunikasi. kedepan tidak boleh tidak, guru dituntut memilki kompetensi-kompetensi yang dapat diterapkan di setiap jenjang pendidikan dan dilaksanakan dalam setiap proses belajar mengajar". Penguasaan teknik akuntansi ini dapat ditunjang dengan ketersediaan guru-guru akuntansi yang kompeten dan profesional. Profesional dalam hal ini dapat dibuktikan dengan kesesuaian antara indikatorindikator kompetensi guru dengan pelaksanaannya dilapangan. Kesesuaian ini dapat menyelaraskan dan meningkatkan tingkat kompetensi guru dalam menyampaikan kegiatan pembelajaran didalam kelas. 


\section{TINJAUAN PUSTAKA}

\section{Pendidikan}

\section{Pengertian Pendidikan}

"Potensi kemanusiaan dalam bermasyarakat dan menjadi manusia seutuhnya dapat dicapai melalui sarana pendidikan" Suardi, (2012). Sedangkan pendidikan menurut Triwiyanto, (2014) adalah "Pendidikan merupakan usaha yang disengajakan untuk tumbuh kembang siswa". Menurut Hafid (2014) “Cerminan dari hasil peradaban suatu bangsa dari hasil pandangan hidup bangsa tersebut merupakan hasil dari filsafat pendidikan" sehingga dari pengertian di atas diketahui bahwa pendidikan merupakan salah satu sarana yang dikembangan dalam suatu peradaban guna membentuk manusia yang berpotensi dan menjadi manusia seutuhnya.

\section{Fungsi Pendidikan}

Fungsi pendidikan merupakan salah satu tugas penting dalam pendidikan. Pengertian dari fungsi pendidikan diantaranya adalah : "Tugas dari pendidikan merupakan untuk menghapus kebodohan dan ketertinggalan di masyarakat" (Suardi, 2012). "Fungsi pendidikan secara mikro merupakan bantuan untuk perkembangan jasmani dan rohani siswa, sedangkan secara makro sebagai bentuk perkembangan masyarakat, budaya dan bangsa" (Ihsan, 2011). Jadi, dapat disimpulkan bahwa fungsi pendidikan adalah membantu masyarakat dalam mengentaskan kebodohan dan membantu perkembangan jasmani dan rohani masyarakat melalui pendidikan peserta didik.

\section{Profesionalisme}

\section{Pengertian Profesionalisme}

Hal yang dibutuhkan untuk menjadi seorang tenaga pendidik berkompeten salah satunya harus profesional dalam bekerja. Profesionalisme guru muncul guna mendukung suatu profesi. "profesionalisme adalah sikap yang mencerminkan sesuatu pekerjaan pokok sebagai profesi yang dilaksanakan secara profesional (Sagala, 2013). Sedangkan menurut Rugaiyah (2011) profesionalisme adalah "sikap yang profesional bercermin pada peraturan undang-undang, kehidupan sosial, maupun pelaksanaan dalam kegiatan profesi secar profesional". Dapat disimpulkan bahwa profesionalisme merupakan sikap profesional dalam melakukan sesuatu profesi secara profesional.

\section{Tenaga Pendidik}

\section{Pengertian Tenaga Pendidik Sebagai Profesi}

Tenaga Pendidik merupakan salah satu elemen yang memiliki peran penting dalam pelaksanaan kegiatan belajar mengajar. Pada pelaksanaannya guru harus mampu berinteraksi dengan anak didiknya. "Guru merupakan tokoh yang paling banyak menjalin interaksi dengan 
siswa. Guru bertugas dalam pelaksanaan kegiatan pembelajaran, menilai hasil kegiatan pembelajaran, membimbing dan berkomunikasi dengan masyarakat", (Sagala, 2013).

Menurut Danim (2013). "Guru merupakan pendidik pada jalur formal yang bertugas untuk mendidik, mengajar, membimbning dan menilai serta mengevaluasi siswa". Dari beberapa pendapat dapat disimpulkan bahwa yang pendidik profesional merupakan pendidik yang berinteraksi dengan peserta didik untuk mendidik, membimbing, mengajar maupun mengevaluasi peserta didik dilingkungan sekolah.

\section{Peran dan Tugas Guru}

Guru dalam pelaksanaannya memiliki banyak sekali peran dan tugas guru yang harus dilaksanakan dan dipatuhi. "Karakter anak didik yang berakhlak mulia, mandiri dan berguna bagi nusa, dan bangsa dibentuk oleh peran guru (Sagala, 2013). Menurut Djamarah (2014) "Guru merupakan suatu profesi yang menuntut perkembangan profesionalisme dalam ilmu pengetahuan dan teknologi". Sehingga dapat disimpulkan bahwa peran guru memiliki suatu tugas untuk membentuk karakteristik siswa yang berkarakter sesuai dengan perkembangan ilmu pengetahuan.

\section{Tanggung Jawab Guru}

"Mencerdaskan kehidupan siswa merupakan tugas seorang guru”, (Djamarah, 2014). Sedangkan menurut Sagala (2013) "Guru merupakan sosok yang harus berusaha untuk mengembangkan ilmunya yang menjadi bidang studi agar tidak ketinggalan jaman". Dalam pengertian di atas dapat disimpulkan bahwa guru memiliki tanggung jawab besar dalam meningkatkan ilmu dibidang studinya guna mencerdaskan kehidupan anak didik bangsa ini.

\section{Kurikullum}

\section{Pengertian Kurikullum}

Pembelajaran yang berlangsung dilingkungan pendidikan harus memiliki pedoman yang bersifat nasional. Pedoman ini berupa kurikulum yang menjadi acuan untuk memudahkan guru dalam menentukan standart. "Kurikulum merupakan suatu pedoman tercetak yang digunakan oleh guru sebagai acuan dalam pengembangan kegiatan pembelajaran dijenjang tertentu (Sagala, 2013)". Literatur lainnya menyatakan bahwa "Kurikullum merupakan suatu perangkat rencana dan aturan mengenai pedoman pelaksanaan kegiatan pelajaran utnuk jenjang pendidikan tertentu (Rusman, 2011)". Dari pengertian diatas dapat disimpulkan bahwa kurikullum merupakan seperangkat dokumen yang bertugas sebagai pedoman penyelenggaraan kegiatan pembelajaran guna tercapainya suatu tujuan pendidikan dilingkup sekolah maupun jenjang pendidikan.

\section{Kompetensi}




\section{Pengertian Kompetensi}

Tenaga pendidik yang profesional harus memiliki karakter yang baik. Karakter ini tertuang dalam kompetensi-kompetensi yang berkaitan erat dengan tugas Guru. “Kompetensi merupakan kemampuan dalam melaksanakan suatu pekerjaan yang diperoleh dari pelatihan dan pendidikan", (Sagala, 2013). Sedangkan menurut literatur lainnya menurut Sanjaya (2010) "Kompetensi merupakan pencapaian dari perilaku rasional sesuai dengan kondisi yang diharapkan". Dari pengertian diatas dapat disimpulkan bahwa kompetensi merupakan suatu aktivitas yang didasari dengan perilaku rasional untuk membetuk kemampuan yang timbul dari pendidikan dan latihan.

\section{Macam Macam Kompetensi}

\section{Kompetensi Pedagogik}

Kompetensi pedagogik meruapakan salah satu aspek penting dalam membentuk guru profesional. "Kompetensi pedagogik merupakan kemampuan guru dalam mengelola kegaitan pembelajaran peserta didik", (Hudiyono, 2012). Menurut Andini, D. M., \& Supardi, E. (2018) "Efektivitas pembelajaran timbul dari pengaruh guru secara simultan dan parsial". Sehingga dapat disimpulkan dari pernyataan diatas bahwa kompetensi pedagogik merupakan kemampuan guru dalam melaksanakan pengelolaan peserta didik di dalam kegiatan pembelajaran.

\section{Kompetensi Kepribadian}

Kompetensi kepribadian merupakan salah satu poin yang memiliki tugas penting dalam membentuk profesionalitas seorang guru. Kompeten kepribadian "Merupakan cerminan diri yang dewasa, berwibawa, berakhlak mulia yang menjadi teladan bagi peserta didik", (Hudiyono, 2012). Menurut Sanjaya (2010) “Guru merupakan cerminan pribadi yang ideal”. Dapat disimpukan dari pengertian diatas bahwa kompetensi kepribadian merupakan cerminan ideal dalam sebuah kepribadian guru yang mantap dan berwibawa.

\section{Kompetensi Sosial}

Kompetensi sosial merupakan salah satu aspek untuk mengukur tingkat interaksi tenaga pendidik maupun guru dilingkungan sekolah maupun sekitarnya. "Kompetensi ini merupakan kemampuan tenaga penddik dalam menjalin interaksi dengan masyarakat sebagai mahluk sosial", (Sanjaya, 2010). Menurut Sagala (2013) “Kompetensi sosial merupakan kemampuan guru dalam berinteraksi dengan orang lain ". Dari pengertian diatas dapat ditarik kesimpulan bahwa kompetensi sosial merupakan kemampuan guru dalam berinteraksi dengan orang lain sebagai bentuk mahluk sosial dalam kehidupan bermasyarakat.

\section{Kompetensi Profesional}


Upaya dalam membentuk kemampuan mendasar seorang guru dalam penguasaan akan teknis pembelajaran menentukan seberapa besar guru dalam profesionalitas bekerja. “Kompetensi profesional merupakan kompetensi yang memiliki hubungan dengan kemampuan guru dalam menyelesaikan tugas keguruannya, (Sanjaya, 2010). Menurut Hudiyono (2012) "Kompetensi profesional merupakan kemampuan yang timbul dari penguasaan materi pembelajaran kompleks". Berdasarkan pengertian diatas dapat ditarik kesimpulan bahwa kompetensi profesional merupakan kompetensi yang berhubungan dengan kemampuan penguasaan materi pembelajaran guna menyelesaikan tugas-tugas keguruan.

\section{Indikator Kompetensi}

Indikator profesionalitas guru terdiri dari empat kompetensi, antara lain :

\section{Kompetensi Pedagogik}

Indikator kompetensi pedagogik menurut Peraturan Menteri Pendidikan Nasional Republik Indonesia Nomor 16 Th 2007 Tentang Standar Kualifikasi Akademik dan Kompetensi Guru menyatakan bahwa : Menguasai Karakteristik peserta didik dari aspek fisik, moral, spritual, sosial, kultural, emosional, dan intelektual, Menguasai Teori belajar dan prinsip-prinsip pembelajaran yang mendidik, Mengembangkan kurikulum yang terkait dengan mata pelajaran yang diampu, Menyelenggarakan pembelajaran yang mendidik, Memanfaatkan teknologi informasi dan komunikasi untuk kepentingan pembelajaran, Memfasilitasi penembangan potensi peserta didik untuk mengaktualisasikan berbagai potensi yang dimiliki, Berkomunikasi secara efektif, empatik dan santun dengan peserta didik, Menyelenggarakan penilaian dan evaluasi proses dan hasil belajar, Memanfaatkan hasil penilaian dan evaluasi untuk kepentingan pembelajaran, Melakukan tindakan reflektif untuk meningkatkan kualitas pembelajaran.

Sedangkan menurut Sagala (2013) memiliki pendangan sebagai berikut "Kompetensi Pedagogik merupakan kemampuan dalam pengelolaan peserta didik meliputi a) pemahaman wawasan guru akan landasan dan filsafat pendidikan; b) guru memahaman potensi dan keberagaman peserta didik; c) guru mampu mengembangkan kurikulum/silabus baik dalam bentuk dokumen maupun implementasi dalam bentuk pengalaman belajar; d) guru mampu menyusun rencana dan strategi pembelajaran berdasarkan standar kompetensi dan kompetensi dasar; e) mampu melaksanakan pembelajaran yang mendidik dengan suasana dialogis dan interaktif. Sehingga pembelajaran menjadi aktif, inovatif, kreatif, efektif dan menyenangkan; f) mampu melakukan evaluasi hasil belajar dengan memenuhi prosedur dan standar yang dipersyaratkan; dan g) mampu mengembangkan bakat dan minat peserta didik melalui kegiatan intrakulikuler dan ekstrakulikuler untuk mengaktualisasikan berbagai potensi yang dimilikinya". Sehingga dapat disimpulkan bahwa indikator kompetensi pedagogik meliputi a) pemahaman akan karakter dan potensi siswa; b) guru mampu menguasai materi dan menyiapkan materi sesuai dengan silabus maupun KI/KD yang berlaku; c) guru mampu menyusun rancangan pembelajaran dengan baik; d) 
guru mampu menguasai teknologi informasi dan komunikasi guna membentuk pembelajaran yang aktif dan inovatif serta interaktif; e) mampu mengevaluasi dan memanfaatkan hasil belajar sesuai dengan prosedur yang berlaku.

\section{Kompetensi Kepribadian}

Indikator kepribadian merupakan aspek-aspek yang memiliki komponen penting dalam menentukan kompetensi kepribadian. Sanjaya (2010) memiliki pandangan sebagai berikut "Sebagai seorang model guru harus memiliki kompetensi yang berhubungan dengan pengembangan kepribadian (personal competencies), diantaranya :a) Kemampuan yang berhubungan dengan pengamalan ajaran agama sesuai dengan keyakinan agama yang dianutnya; b) Kemampuan untuk menghormati dan menghargai antarumat beragama; c) Kemampuan untuk berperilaku sesuai dengan norma, aturan dan sistem nilai yang berlaku dimasyarakat; d)Mengembangkan sifat-sifat terpuji sebagai sorang guru misalnya, sopan santun dan tata krama; e) Bersifat demokratis dan terbuka terhadap pembaruan dan kritik".

Kompetensi kepribadian menurut Peraturan Menteri Pendidikan Nasional Republik Indonesia Nomor 16 Th 2007 Tentang Standar Kualifikasi Akademik dan Kompetensi Guru menyatakan bahwa : a) bertindak sesuai dengan norma agama, hukum,sosial,dan kebudayaan nasional indonesia ;b) menampilkan diri sebagai pribadi yang jujur, berakhlak mulia, dan teladan bagi peserta didik dan masyarakat; c) menampilkan diri sebagai pribadi yang mantap, stabil, dewasa, arif dan berwibawa; d) menunjukkan etos kerja. Tanggung jawab yang tinggi, rasa bangga menjadi guru dan percaya diri; e) menjunjung tinggi kode etik profesi guru. Sehingga dapat disimpulkan bahwa kompetensi kepribadian memiliki indikator antara lain a) memiliki tindkaan yang sesuai dengan norma agama, hukum, maupun sosial dan budaya; b) memiliki rasa menghormati dan menghargai antar manusia; c) memiliki perilaku yang santun sesuai norma sosial yang berlaku; d) memiliki etos kerja yang tinggi dan menjunjung tinggi kode etik guru.

\section{Kompetensi Sosial}

Kompetensi sosial merupakan salah satu kompetensi yang memiliki hubungan interaksi antar manusia. Menurut Sanjaya (2010) memiliki pandangan sebagai berikut "Kompetensi ini berhubungan dengan kemampuan guru sebagai anggota masyarakat dan sebagaai mahluk sosial meliputi :a) Kemampuan untuk berinteraksi dan berkomunikasi dengan teman sejawat untuk meningkatkan kemampuan profesional; b) Kemampuan untuk mengenal dan memahami fungsifungsi setiap lembaga kemasyarakatan; c) Kemampuan untuk menjalin kerja sama baik secara individiual maupun secara kelompok".

Indikator kompetensi sosial menurut Peraturan Menteri Pendidikan Nasional Republik Indonesia Nomor 16 Th 2007 Tentang Standar Kualifikasi Akademik dan Kompetensi Guru menyatakan bahwa: a) Bersikap inklusif, bertindak objektif, serta tidak diskriminatif karena pertimbangan jenis kelamin, agama, ras, kondisi fisik, latar belakang keluarga, dan status sosial 
ekonomi;b) Beradaptasi di tempat bertugas di seluruh wilayah Republik Indonesia yang memiliki keragaman sosial budaya;c) Berkomunikasi dengan komunitas profesi sendiri dan profesi lain secara lisan dan tulisan atau bentuk lain. Kesimpulan dari indikator kompetensi sosial tersebut antara lain :a) kemampuan berinteraksi dan berkomunikasi secara baik dengan lingkungan kerja guna meningkatkan profesional; b) mampu beradaptasi dilingkungan kerja; c) serta mampu menjalin komunikasi dan kerja sama dengan kelompok tenaga pendidik yang lainnya.

\section{Kompetensi Profesional}

Kompetensi profesional merupakan kompetensi yang memiliki indikator untuk mengukur tingkat profesionalitas guru. Menurut Sanjaya (2010) memiliki pandangan sebagai berikut "Beberapa kemampuan yang berhubungan dengan kompetensi ini diantaranya : a) Kemampuan untuk menguasai landasan pendidikan, misalnya paham akan tujuan pendidikan yang harus dicapai baik tujuan nasional, tujuan institusional, tujuan kurikuler, dan tujuan pembelajaran; b) Pemahaman dalam bidang psikologi pendidikan, misalnya paham tentang tahapan perkembangan siswa, paham tentang teori-teori belajar dan lain sebagainya; c) Kemampuan dalam penguasaan materi pelajaran sesuai dengan bidang studi yang diajarkannya; d) Kemampuan dalam mengaplikasikan berbagai metodologi dan strategi pembelajaran; e) Kemampuan merancang dan memanfaatkan berbagai media dan sumber belajar; f) Kemampuan dalam melaksanakan evaluasi pembelajaran; g) Kemampuan dalam menyusun progam pembelajaran; h) Kemampuan dalam melaksanakan unsur-unsur penunjang, misalnya paham akan administrasi sekolah, bimbingan, dan penyuluhan; i) Kemampuan dalam melaksanakan penelitian dan berpikir ilmiah untuk meningkatkan kinerja".

Indikator kompetensi kepribadian menurut Peraturan Menteri Pendidikan Nasional Republik Indonesia Nomor 16 Th 2007 Tentang Standar Kualifikasi Akademik dan Kompetensi Guru menyatakan bahwa: a) Menguasai materi, struktur, konsep, dan pola pikir keilmuan yang mendukung mata pelajaran yang diampu; b) Menguasai standar kompetensi dan kompetensi dasar mata pelajaran yang diampu; c) Mengembangkan materi pembelajaran yang diampu secara kreatif; d) Mengembangkan keprofesionalan secara berkelanjutan dengan melakukan tindakan reflektif; e) Memanfaatkan teknologi informasi dan komunikasi untuk mengembangkan diri.

Kesimpulan dari indikator kompetensi profesional diatas antara lain : a) guru harus mampu menguasai materi keilmuan yang berhubungan dengan mata pelajaran diampu; b) menguasai standar kompetensi yang diampu; c) mampu mengembangkan materi pembelajran secara efektif, kreatif dan inovatif; d) mampu mengembangkan profesionalitas ilmu guna penguasaan materi pembelajaran; e) mampu menguasai teknologi informasi dan komunikasi sesuai perkembangan jaman.

\section{METODE PENELITIAN}


Penelitian yang dilaksanakan oleh peneliti dalam hal ini menggunakan pendekatan kualitatif. Tempat penelitian berikut dilakukan di SMKN 1 Bringin, Desa Krompol, Kecamatan Bringin, Kabupaten Ngawi. Dalam penelitian ini, peneliti langsung melakukan 1. studi kelapangan, 2. wawancara, 3. Dokumentasi guna memperoleh data yang relevan dengan subjek yang diteliti.

\section{Sumber Data}

Sumber data dari penelitian berikut ada tiga, diantaranya adalah observasi, wawancara dan dokumen maupun arsip. Observasi adalah teknik pengamatan langsung baik terhadap objek maupun subjek penelitian. Diantaranya meliputi : a) dokumen pembelajaran; b) pelaksanaan kegiatan pembelajaran; c) komunikasi di lingkungan kerja. wawancara adalah teknik untuk memperoleh data dengan mengajukan pertanyaan kepada narasumber guna memperoleh informasi yang sesuai dengan aspek yang diteliti. Meliputi a) aspek kompetensi pedagogik; b) aspek kompetensi kepribadian; c) aspek kompetensi profesional; d) aspek kompetensi sosial.dokumen yang dipakai dalam penelitian ini Meliputi : a) dokumen kegiatan pembelajaran; b) dokumen penilaian siswa; c) dokumen kode etik guru; d) dokumen acuan pembelajaran.

\section{Instrumen Penelitian}

Aspek Instrumen penelitian ini merupakan peneliti pribadi, dengan dibantu alat-alat instrumen bantu yang berfungsi untuk mendukung dalam teknis pengumpulan data. Beberapa instrumen yang digunakan dalam penelitian ini dapat dilihat di bawah ini sesuai dengan teknik yang digunakan:

\section{Observasi}

Observasi ini berupa pengamatan langsung kepada objek yang diteliti bertempat diSMKN 1 Bringin dengan guru yang bersangkutan antara meliputi: (1) Ketua Jurusan Akuntansi dan Keuangan Lembaga; (2) Guru Produktif Akuntansi 1; (3) Guru Produktif Akuntansi2.

\section{Wawancara}

Pelaksanaan teknis wawancara menggunakan daftar pertanyaan yang telah disusun dan merekam jawaban dari narasumber atau informan menggunakan tape recorder. Berikut merupakan poin-poin yang berkaitan dengan informasi yang hendak peneliti ajukan, diantaranya adalah: (a) Aspek Kompetensi Pedagogik; (b) Aspek Kompetensi Profesional; (c) Aspek Kompetensi Kepribadian; (d) Aspek Kompetensi Sosial.

\section{Dokumentasi}

Dokumentasi merupakan teknik analisis terhadap dokumen yang relevan dengan kebutuhan peneliti. Peneliti menggunakan kamera dan scanner untuk mengumpulkan bukti-bukti 
dokumen dari lapangan berupa foto maupun file scan yang digunakan sebagai salah satu penunjak aspek yang diteliti. Dokumen yang peneliti analisis dan didokumentasikan berupa RPP, Daftar Nilai, Jurnal Guru, Daftar Hadir Siswa.

\section{Teknik Pengumpulan Data}

Teknik pengumpulan data yang dilakukan peneliti untuk mengumpulkan data antara lain :

\section{Observasi}

Peneliti mengupayakan dalam mengamati secara langsung mengenai aspek-aspek yang mendukung profesionalitas guru, baik kompetensi pedagogik, kompetensi kepribadian, kompetensi profesional, dan kompetensi sosial.

\section{Wawancara}

Peneliti melakukan wawancara terhadap guru akuntansi dan lembaga keuangan guna mengetahui upaya beliau dalam meningkatkan profesionalitas guru, baik dari kompetensi pedagogik, kompetensi kepribadian, kompetensi profesional, dan kompetensi sosial.

\section{Dokumentasi}

Dokumentasi dalam hal ini untuk memperoleh data maupun informasi yang menunjang peneliti dalam melakukan penelitian mengenai profesionalitas guru.

\section{Teknik Analisis Data}

Peneliti melakukan analisis data dari hasil kegiatan observasi dilapangan, hasil wawancara, dan dokumentasi yang diambil peneliti. Hasil dari pengumpulan data tersebut akan diolah oleh peneliti lebih lanjut. Peneliti akan membuat pembahasan dari data tersebut secara mendalam dan konsisten guna memperoleh hasil data yang akurat dan relevan. Hal ini dilakukan guna memudahkan dalam melakukan penarikan kesimpulan yang digunakan sebagai tahap akhir dalam penyusunan laporan.

\section{Prosedur Penelitian}

Prosedur penelitian yang dilakukan peneliti terdiri dari beberapa tahap, antara lain :

\section{Tahap Persiapan}

Tahap persiapan yakni merupakan langkah untuk mempersiapkan bahan wawancara, alat dokumentasi serta persiapan obervasi di SMKN 1 Bringin sebelum hari pelaksanaan.

\section{Tahap Pelaksanaan}

Pelaksanaan dari kegiatan observasi, wawancara dan dokumentasi di SMKN 1 Bringin guna memperoleh data sebagai bahan analisis untuk ditarik kesimpulan.

\section{Tahap Pelaporan}


Tahap pelaporan ini peneliti melakukan kegiatan menyusun laporan kegiatan peneliatan berdasarkan hasil dari analisis di SMKN 1 Bringin.

\section{Teknik Keabsahan Data}

Penelitian ini, peneliti untuk menentukan keabsahan data menggunakan teknik triangulasi sumber dimana peneliti menggunakan obesrvasi, wawancara dan dokumentasi guna memperoleh data yang sama dari sumber yang berbeda.

\section{HASIL DAN PEMBAHASAN}

Penelitian ini dilaksanakan di SMKN 1 Bringin pada jurusan Akuntansi dan Keuangan Lembaga , khususnya kepada guru produktif akuntansi dan keuangan lembaga sejumlah 4 orang. Akan tetapi salah seorang guru bertindak sebagai peneliti. Sehinggga dalam pelaksaan penelitian ini, aspek yang diteliti berjumlah tiga orang. Pemilihan sampel ini, dianggap peneliti telah mewakili seluruh aspek yang diharapkan oleh penulis. Meliputi Ketua Jurusan Akuntansi dan Keuangan Lembaga, Guru Produktif Akuntansi I dan Guru Produktif Akuntansi II. Guru produktif akuntansi ini mengajar baik pada kelas X AKL, kelas XI AKL maupun kelas XII AKL. Keseluruhan guru ini melaksanakan kurikulum 2013, terutama jurusan akuntansi dan keuangan lembaga.

Peneliti melakukan kegiatan observasi yang bertempat di SMKN 1 Bringin, mewawancarai guru sebanyak 3 orang, dan mendokumentasikan dokumen yang dibutuhkan oleh peneliti. Untuk mempermudah penyajian data maka masing masing narasumber.

Observasi dokumen memperoleh data dari narasumber sejumlah 3 orang, bedasarakan latar belakang pendidikan maupun lama mengajar sebagai guru.

Proses untuk mengumpulkan informasi mengenai kompetensi guru, meliputi kompetensi pedagogik, kompetensi kepribadian, kompetensi profesional dan kompetensi sosial. Berikut merupakan transkip pertanyaan wawancara peneliti :

Tabel 1.1 Daftar Pertanyaan Wawancara

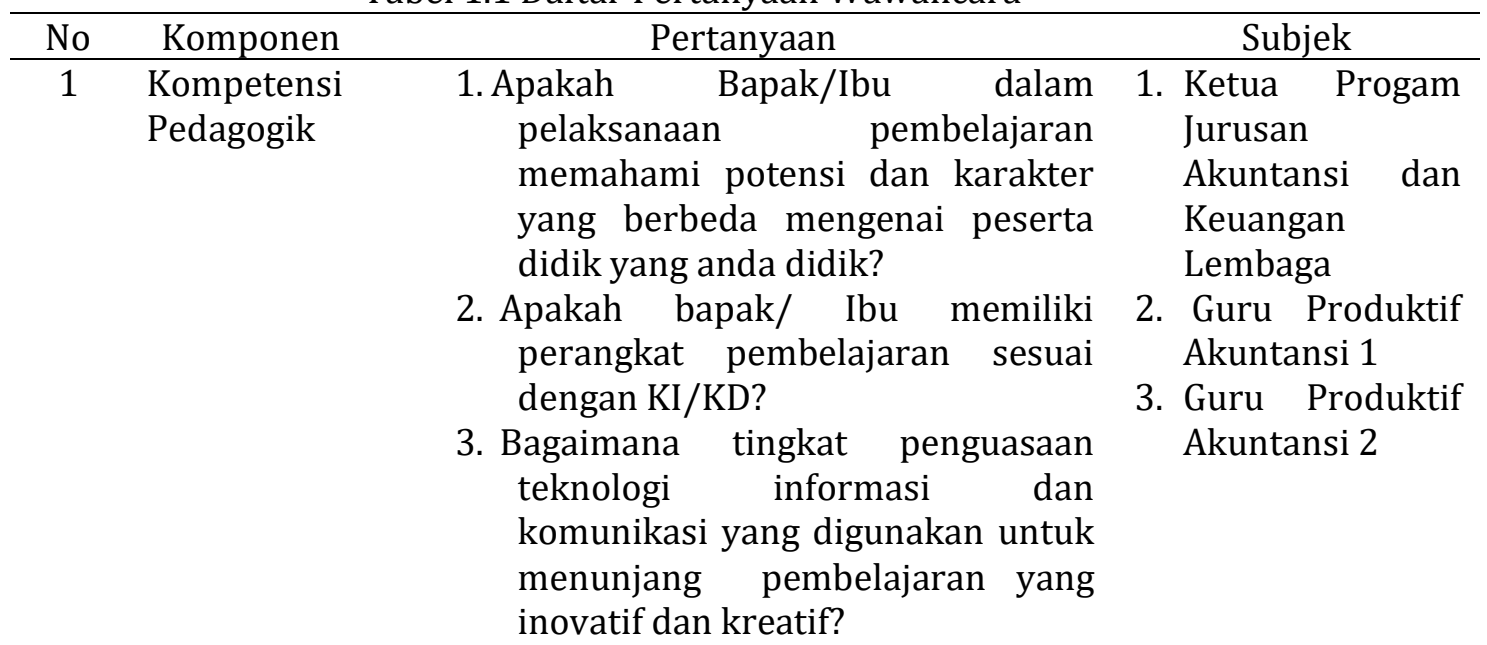




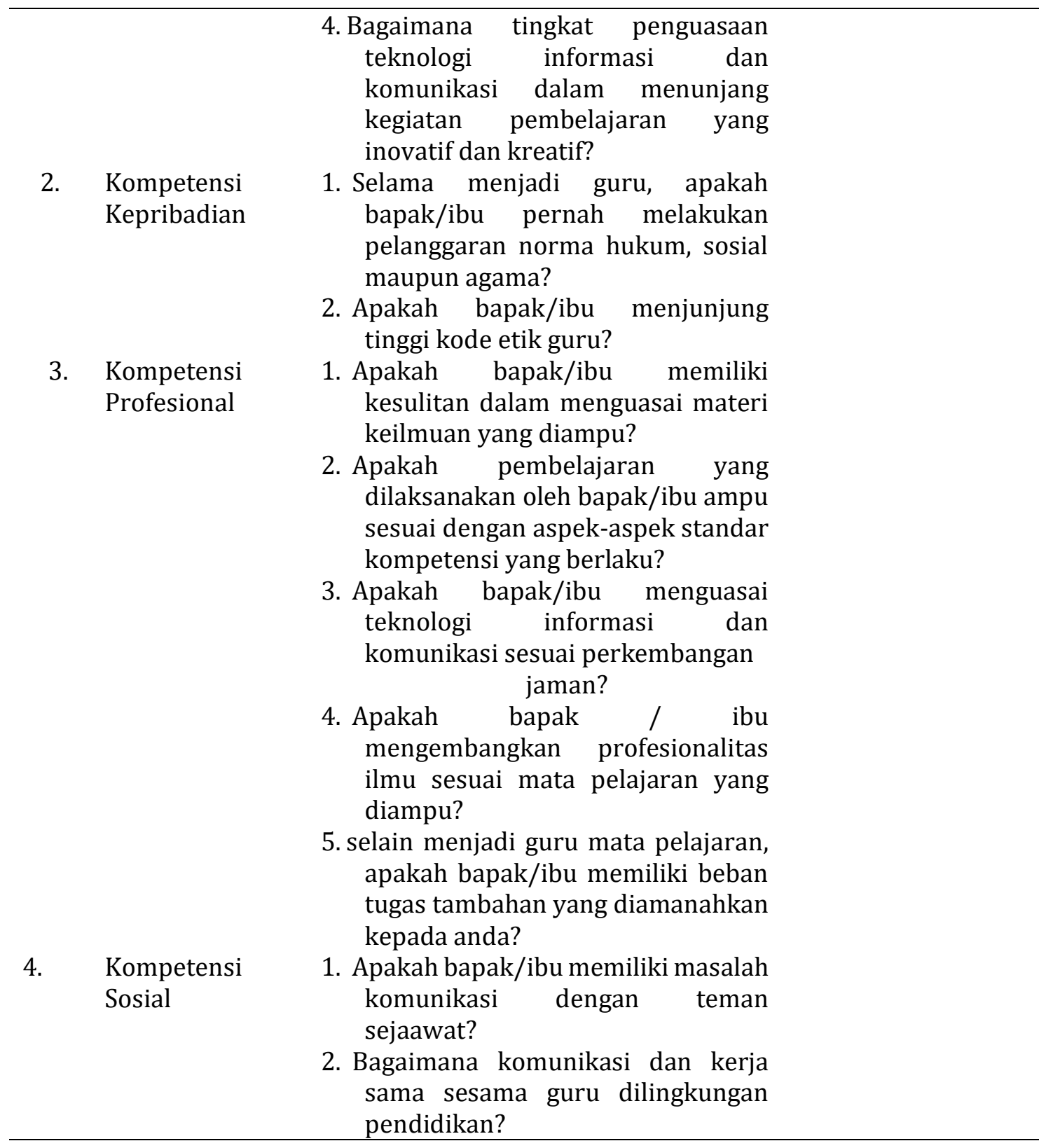

\section{Validasi Data}

Untuk memperoleh validitas data dapat menggunakan teknik triangulasi sumber.. Berikut merupakan validitas mengenai kompetensi guru. Dari hasil observasi, wawancara, dan dokumentasi Diantaranya :

Hasil Observasi mengenai kompetensi pedagogik, kompetensi kepribadian, kompetensi profesional dan kompetensi sosial dilingkungan pendidikan SMKN 1 Bringin.

Tabel 1.2 Validitas Hasil Observasi

\begin{tabular}{llllll}
\hline No & Nama & Narasumber & Narasumber & Narasumber & Keterangan \\
& Komponen & Pertama & Kedua & Ketiga & \\
\hline 1. & Kompetensi & Guru & Guru & Guru mampu & VALID \\
& Pedagogik & melakukan & melakukan & melakukan & \\
& Pelaksanaan & kegiatan & interaksi dan & kegiatan & \\
& kegiatan & pembelajaran & melakukan & pembelajaran & \\
& belajar- & dengan baik & aktivitas & sesuai & \\
\hline
\end{tabular}




\begin{tabular}{|c|c|c|c|c|c|}
\hline 2. & $\begin{array}{l}\text { Kompetensi } \\
\text { Kepribadian } \\
\text { (guru } \\
\text { menjadi } \\
\text { teladan dan } \\
\text { panutan } \\
\text { siswa) }\end{array}$ & $\begin{array}{l}\text { Guru } \\
\text { mencerminkan } \\
\text { pribadi yang } \\
\text { bersahaja }\end{array}$ & $\begin{array}{l}\text { Guru rutin } \\
\text { melakukan } \\
\text { aktivitas } \\
\text { keagamaan } \\
\text { secara baik } \\
\text { dan agamis }\end{array}$ & $\begin{array}{l}\text { Guru } \\
\text { memiliki } \\
\text { tindak } \\
\text { tanduk yang } \\
\text { sopan dan } \\
\text { bersahaja }\end{array}$ & VALID \\
\hline 3. & $\begin{array}{l}\text { Kompetensi } \\
\text { Profesional } \\
\text { (penggunaan } \\
\text { alat bantu } \\
\text { pengajaran } \\
\text { yang sesuai } \\
\text { dibidangnya) }\end{array}$ & $\begin{array}{l}\text { Guru } \\
\text { menggunakan } \\
\text { perangkat } \\
\text { komputer } \\
\text { dalam kegiatan } \\
\text { pembelajaran }\end{array}$ & $\begin{array}{l}\text { Guru } \\
\text { mengenalkan } \\
\text { alat-alat } \\
\text { pembelajaran } \\
\text { akuntansi yang } \\
\text { umum } \\
\text { digunakan }\end{array}$ & $\begin{array}{l}\text { Guru } \\
\text { mengenalkan } \\
\text { penggunaan } \\
\text { aplikasi } \\
\text { akuntansi }\end{array}$ & VALID \\
\hline 4. & $\begin{array}{l}\text { Kompetensi } \\
\text { Sosial } \\
\text { (aktivitas } \\
\text { komunikasi } \\
\text { dengan } \\
\text { lingkungan } \\
\text { kerja) }\end{array}$ & $\begin{array}{l}\text { Guru } \\
\text { berkomunikasi } \\
\text { dengan siswa } \\
\text { secara baik } \\
\text { dan memiliki } \\
\text { cerminan guru } \\
\text { yang totalitas } \\
\text { dan sesuai } \\
\text { dengan } \\
\text { koridor } \\
\text { seorang guru }\end{array}$ & $\begin{array}{l}\text { Guru menjalin } \\
\text { komunikasi } \\
\text { dengan teman } \\
\text { sesama guru } \\
\text { tanpa adanya } \\
\text { halangan } \\
\text { dalam } \\
\text { berkomunikasi }\end{array}$ & $\begin{array}{l}\text { Guru antusias } \\
\text { dalam } \\
\text { menjalin } \\
\text { komunikasi } \\
\text { dengan } \\
\text { masyarakat } \\
\text { umum }\end{array}$ & VALID \\
\hline
\end{tabular}

Validasi data mengenai pemahaman kompetensi pedagogik oleh guru akuntansi dan keuangan lembaga di SMKN 1 Bringin.

Tabel 1.3 Validitas kompetensi pedagogik

\begin{tabular}{|c|c|c|c|c|}
\hline No & Narasumber Pertama & $\begin{array}{l}\text { Narasumber } \\
\text { Kedua }\end{array}$ & $\begin{array}{l}\text { Narasumber } \\
\text { Ketiga }\end{array}$ & Keterangan \\
\hline 1 & $\begin{array}{l}\text { Ya, karena pada dasarnya } \\
\text { setiap anak memiliki } \\
\text { karakter yang berbeda, } \\
\text { dan memiliki ciri khas } \\
\text { yang berbeda juga. }\end{array}$ & $\begin{array}{l}\text { Ya jelas gus, anak } \\
\text { itu karunia } \\
\text { tuhan. Pasti akan } \\
\text { memiliki } \\
\text { karakter yang } \\
\text { berbeda maupun } \\
\text { potensi yang } \\
\text { berbeda pula. }\end{array}$ & $\begin{array}{l}\text { Ya iyalah, } \\
\text { banyak siswa } \\
\text { punya } \\
\text { karakter yang } \\
\text { berbeda. }\end{array}$ & VALID \\
\hline 2 & $\begin{array}{l}\text { Ya, Saya selalu mengajar } \\
\text { dengan berpedoman dari } \\
\text { Perangkat Pembelajaran. }\end{array}$ & $\begin{array}{l}\text { Alhamdulillah } \\
\text { sesuai. }\end{array}$ & $\begin{array}{l}\text { Iya , sesuai } \\
\text { dengan } \\
\text { kurikulum } \\
2013\end{array}$ & VALID \\
\hline 3 & Saya masih tahap belajar, & $\begin{array}{l}\text { alhamdulillah } \\
\text { gus, soalnya } \\
\text { bapak itu } \\
\text { mengajar }\end{array}$ & $\begin{array}{l}\text { Sejauh ini } \\
\text { cukup } \\
\text { menguasai, } \\
\text { karena saya }\end{array}$ & $\begin{array}{l}\text { VALID dengan } \\
\text { catatan bahwa } \\
\text { narasumber } \\
\text { pertama masih }\end{array}$ \\
\hline
\end{tabular}




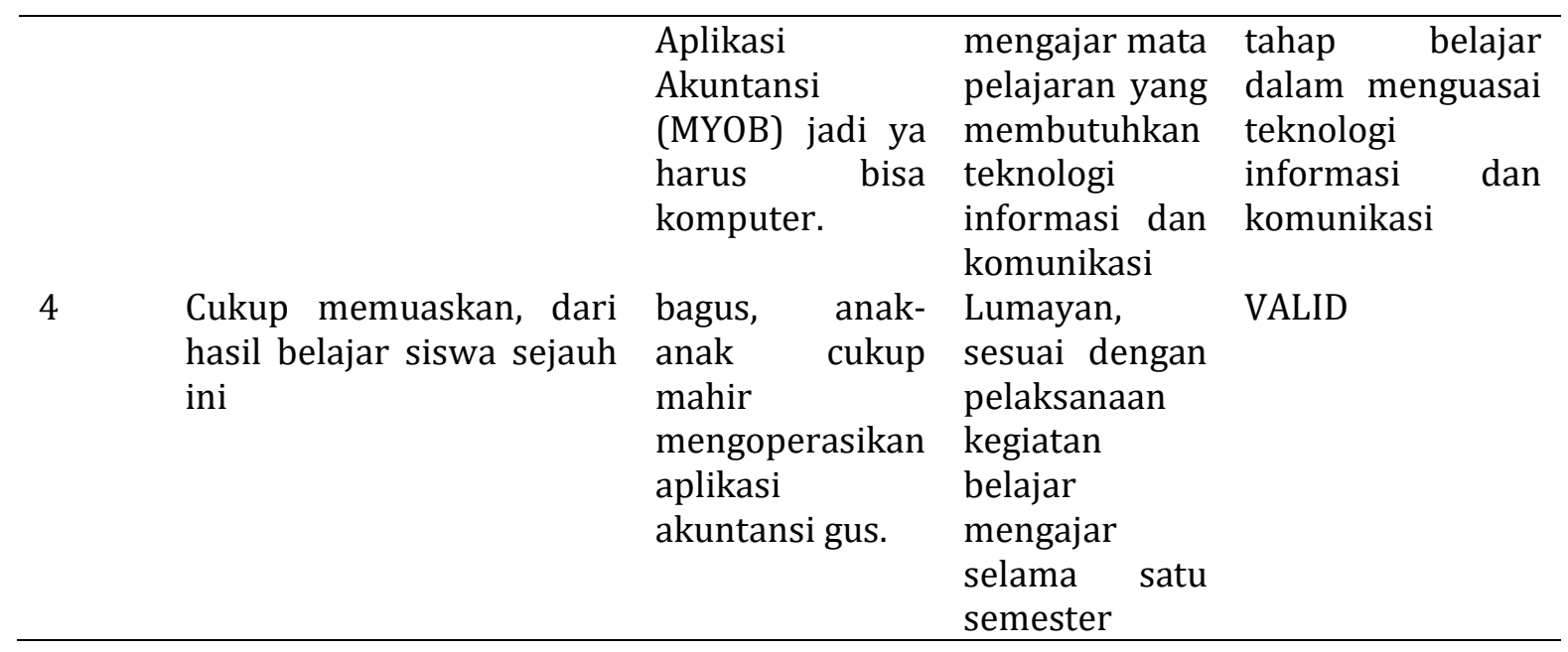

Validasi data mengenai pemahaman kompetensi kepribadian oleh guru akuntansi dan keuangan lembaga di SMKN 1 Bringin. Informasi mengenai pemahaman kompetensi kepribadian diperoleh dengan melakukan wawancara dengan ketiga narasumber yakni guru akuntansi dan keuangan lembaga. Data dari hasil wawancara antara lain :

Tabel 1.4 Validitas kompetensi kepribadian

\begin{tabular}{|c|c|c|c|c|}
\hline No & $\begin{array}{c}\text { Narasumber } \\
\text { Pertama }\end{array}$ & $\begin{array}{l}\text { Narasumber } \\
\text { Kedua }\end{array}$ & $\begin{array}{c}\text { Narasumber } \\
\text { Ketiga }\end{array}$ & Keterangan \\
\hline 1 & $\begin{array}{lr}\text { Insya } & \text { Allah } \\
\text { tidak, } & \text { dan } \\
\text { jangan } & \text { sampai } \\
\text { terjadi } & \end{array}$ & $\begin{array}{l}\text { Ya tidak gus, } \\
\text { jangan } \\
\text { sampailah. } \\
\text { Pokok jangan } \\
\text { sampai terjadi }\end{array}$ & $\begin{array}{l}\text { Tidak, sama } \\
\text { sekali tidak. }\end{array}$ & VALID \\
\hline 2 & ya, itu pasti & $\begin{array}{l}\text { Ya iyalah gus, } \\
\text { itu kan profesi } \\
\text { bapak. }\end{array}$ & $\begin{array}{l}\text { Selalu. Karena } \\
\text { itu profesi saya }\end{array}$ & VALID \\
\hline
\end{tabular}

Validasi data mengenai pemahaman kompetensi profesional oleh guru akuntansi dan keuangan lembaga di SMKN 1 Bringin.

Informasi mengenai pemahaman kompetensi profesional diperoleh dengan melakukan wawancara dengan ketiga narasumber yakni guru akuntansi dan keuangan lembaga. Data yang terkumpul dari hasil wawancara antara lain :

Tabel 1.5 Validitas kompetensi profesional

\begin{tabular}{lllll}
\hline No & \multicolumn{1}{c}{$\begin{array}{c}\text { Narasumber } \\
\text { Pertama }\end{array}$} & \multicolumn{1}{c}{$\begin{array}{c}\text { Narasumber } \\
\text { Kedua }\end{array}$} & $\begin{array}{c}\text { Narasumber } \\
\text { Ketiga }\end{array}$ & Keterangan \\
\hline 1 & sedikit, & sedikit, & saya sedikit & VALID \\
& terutama & terutama untuk & kesulitan & \\
& untuk mata & mata pelajaran & dalam & \\
pelajaran baru & Akuntansi & mengampu & \\
& di Kurikulum & Pemerintahan & mata pelajaran & \\
& 2013 yang & & yang & \\
& revisi terkini & & berhubungan & \\
& & & dengan pajak. & \\
2 & Ya, mata & Iya gus, sesuai & Ya, saya selalu VALID \\
& pelajaran yang dengan & merujuk pada & \\
\hline
\end{tabular}




saya ampu
sesuai dengan
pembagian
tugas yang
disahkan
dengan SK

3 Saya masih
tahap belajar
untuk poin ini

Iya, Saya
diamanahkan
sebagai Ketua
Progam
Keahlian
Akuntansi dan
Lembaga
Keuangan,
Ketua Bank
Mini, serta
Tergabung
pada Tim
Kelompok
Kerja Prakerin
maupun Tim
Fungsionaris.

Kurikulum

2013

terbaru..

Iya, menggunakan saya alat komunikasi untuk menjalin hubungan dengan temanteman guru agar mudah bertukar informasi.

Iya gus, bapak selalu berusaha ikut pelatihan, seminar, atau kelas pintar untuk menunjang profesionalisme ilmu dan bapak ikut progam sertifikasi keahlian guru.

bapak bertugas sebagai Wakasek Kesiswaan,

Kurikulum 2013
Ya, saya selalu Ya, saya selalu mengikuti perkembangan teknologi informasi dan komunikasi berusaha.

VALID dengan catatan bahwa narasumber pertama masih dalam tahap belajar untuk mengikuti perkembangan teknologi informasi dan komunikasi

VALID

$$
\text { saya }
$$

VALID

tergabung di Tim Kelompok Kerja Prakerin dan Wali Kelas.

Validasi data mengenai pemahaman kompetensi sosial oleh guru akuntansi dan keuangan lembaga di SMKN 1 Bringin. Informasi mengenai pemahaman kompetensi sosial diperoleh dengan melakukan wawancara dengan ketiga narasumber yakni guru akuntansi dan keuangan lembaga. Data dari hasil wawancara antara lain :

Tabel 1.6 Validitas kompetensi sosial 


\begin{tabular}{|c|c|c|c|c|}
\hline No & $\begin{array}{c}\text { Narasumber } \\
\text { Pertama }\end{array}$ & $\begin{array}{c}\text { Narasumber } \\
\text { Kedua }\end{array}$ & $\begin{array}{c}\text { Narasumber } \\
\text { Ketiga }\end{array}$ & Keterangan \\
\hline 1 & Sejauh ini tidak & $\begin{array}{l}\text { Alhamdulillah } \\
\text { tidak pernah } \\
\text { gus. }\end{array}$ & $\begin{array}{l}\text { Tidak, sama } \\
\text { sekali belum } \\
\text { pernah }\end{array}$ & VALID \\
\hline 2 & $\begin{array}{l}\text { komunikasi } \\
\text { berlangsung } \\
\text { dengan baik, } \\
\text { terutama } \\
\text { dengan teman- } \\
\text { teman MGMP } \\
\text { sesama guru } \\
\text { produktif } \\
\text { akuntansi. }\end{array}$ & $\begin{array}{l}\text { Lancar, baik di } \\
\text { MGMP atau di } \\
\text { sekolah semua } \\
\text { terjalin dengan } \\
\text { baik. }\end{array}$ & $\begin{array}{l}\text { komunikasi } \\
\text { berjalan } \\
\text { dengan baik } \\
\text { sejauh ini }\end{array}$ & VALID \\
\hline
\end{tabular}

Hasil Dokumentasi mengenai kompetensi pedagogik, kompetensi kepribadian, kompetensi profesional dan kompetensi sosial dilingkungan pendidikan SMKN 1 Bringin:

\begin{tabular}{|c|c|c|c|c|c|}
\hline No & $\begin{array}{l}\text { Nama } \\
\text { Komponen }\end{array}$ & $\begin{array}{l}\text { Narasumber } \\
\text { Pertama }\end{array}$ & $\begin{array}{l}\text { Narasumber } \\
\text { Kedua }\end{array}$ & $\begin{array}{l}\text { Narasumber } \\
\text { Ketiga }\end{array}$ & Keterangan \\
\hline 1. & $\begin{array}{l}\text { Kompetensi } \\
\text { Pedagogik } \\
\text { (Kepemilikan } \\
\text { Perangkat } \\
\text { Pembelajaran } \\
\text { sesuai dengan } \\
\text { silabus dan } \\
\text { KI/KD) }\end{array}$ & ADA & ADA & $\mathrm{ADA}$ & VALID \\
\hline 2. & $\begin{array}{l}\text { Kompetensi } \\
\text { Kepribadian } \\
\text { (Pemahaman } \\
\text { tentang Kode } \\
\text { Etik) }\end{array}$ & ADA & ADA & ADA & VALID \\
\hline 3. & $\begin{array}{l}\text { Kompetensi } \\
\text { Profesional } \\
\text { (penggunaan } \\
\text { alat bantu } \\
\text { pengajaran } \\
\text { yang sesuai } \\
\text { dibidangnya) }\end{array}$ & ADA & $\mathrm{ADA}$ & ADA & VALID \\
\hline 4. & $\begin{array}{l}\text { Kompetensi } \\
\text { Sosial } \\
\text { (bukti } \\
\text { komunikasi } \\
\text { dengan rekan } \\
\text { sejawat) }\end{array}$ & ADA & $\mathrm{ADA}$ & $\mathrm{ADA}$ & VALID \\
\hline
\end{tabular}

\section{Analisis Data}

Analisis data dari hasil penelitian mengenai kompetensi guru di SMKN 1 Bringin. Peneliti memperoleh data tentang kompetensi guru meliputi : 1) kompetensi pedagogik; 2) kompetensi kepribadian; 3)kompetensi profesional; dan 4) kompetensi sosial. Adapun data berikut adalah 
Data yang diperoleh mengenai kompetensi pedagogik dapat diketahui dari hasil penelitian ketiga narasumber tidak mengalami kesulitan dalam menyusun perangkat pembelajaran sesuai dengan KI/KD yang tertuang pada kurikulum 2013. Guru tidak mengalami kesulitan dalam menelaah potensi dan karakter siswa serta guru masih memiliki hasrat untuk belajar menguasai teknologi informasi dan komunikasi guna membentuk pembelajaran yang inovatif.

\section{Kompetensi Kepribadian}

Data yang diperoleh dari hasil penelitian mengenai kompetensi kepribadian bahwa dari ketiga narasumber tidak pernah melakukan pelanggaran norma hukum, agama, maupun sosial. Menjunjung tinggi kode etik guru, serta selalu menghormati antar sesama umat manusia.

\section{Kompetensi Profesional}

Dari data yang diperoleh mengenai kompetensi profesional dapat diketahui bahwa guru sedikit mengalami kesulitan dalam menguasai mata pelajaran baru yang terdapat dikurikulum 2013. Guru dituntut untuk mampu menguasai perkembangan teknologi informasi dan komunikasi yang terbaru untuk menunjang pembelajaran. Serta wajib mengikuti profesionalitas ilmu untuk meningkatkan penguasaan materi pembelajaran.

\section{Kompetensi Sosial}

Dari data yang diperoleh dari hasil penelitian mengenai kompetensi sosial dapat diketahui bahwa ketiga narasumber tidak mengalami kendala dalam beradaptasi dilingkungan kerja. Segala aspek bersinergi sesuai dengan alur sebuah pekerjaan. Komunikasi antar rekan kerja maupun teman sejawat sesama guru produktif akuntansi terjalin dengan baik. Tanpa ada satu masalah yang menghalangi.

\section{KESIMPULAN}

Kompetensi guru merupakan kompetensi yang memiliki peran meningkatkan profesionalisme guru. Kompetensi memiliki beberapa aspek yakni 1) kompetensi pedagogik; 2) kompetensi kepribadian; 3) kompetensi profesional dan 4) kompetensi sosial. Setiap kompetensi ini memiliki tugas masing-masing dalam profesi guru. Kompetensi pedagogik memiliki peran aktif untuk membentuk guru yang terstruktur dan sistematis dalam pelaksanaan kegiatan pembelajaran. Kompetensi kepribadian berperan untuk membentuk guru sebagai cermin manusia yang bersahaja. Memiliki pribadi yang luhur, berwawasan luas serta tidak pernah melanggar norma-norma yang ada dimasyarakat.

Kompetensi profesional memiliki tugas untuk membentuk guru yang aktif dalam mengikuti perkembangan keilmuan dalam dunia pendidikan. Aktif mengikuti kegiatan pembelajaran seperti progam sertifikasi untuk mengasah kemampuan profesionalitas. Kompetensi ini menuntut guru untuk mampu menguasai teknologi informasi dan komunikasi yang mengikuti perkembangan jaman. Selain itu, kompetensi sosial memiliki peran aktif untuk membentuk guru yang bersahaja 
dimana guru memiliki wibawa dan disegani dilingkungan masyarakat. Mampu beradaptasi dengan lingkungan pendidikan. Menjalin komunikasi dengan baik dengan sesama rekan kerja, lingkungan sosial maupun dengan teman sejawat MGMP sesama guru produktif akuntansi yang berada wilayah kerjanya. Serta mampu bekerja sama dengan tenaga pendidik lainnya secara antusias dan profesional.

\section{DAFTAR PUSTAKA}

Andini, D. M., \& Supardi, E. (2018). Kompetensi Pedagogik Guru Terhadap Efektivitas Pembelajaran Dengan Variabel Kontrol Latar Belakang Pendidikan Guru.Jurnal Pendidikan Manajemen Perkantoran, 1(2), 1-7.

Anwar Hafid, M. P. (2014). Konsep Dasar Ilmu Pendidikan. Bandung: Alfabeta.

Danim, P. D. (2013). Profesionalisme dan Etika Profesi Guru. Bandung: Alfabeta.

E. Mulyasa, M. (2015). Guru Dalam Implementasi Kurikulum 2013. Bandung: PT Remaja Rosdakarya.

Goodwin, A. L., \& Kosnik, C. (2013). Quality teacher educators= quality teachers? Conceptualizing essential domains of knowledge for those who teach teachers. Teacher Development, 17(3), 334-346.

Hudiyono, M. (2012). Membangun karakter Siswa Melalui Profesionalisme Guru dan Gerakan Pramuka. Jakarta: Esensi.

Ihsan, D. H. (2011). Dasar-Dasar Kependidikan. Jakarta: PT Rineka Cipta.

Indonesia, P. M. P. N. R. (2007). Nomor 16 Tahun 2007 tentang Standar Kualifikasi Akademik dan Kompetensi Guru. Biro Hukum dan Organisasi Departemen Pendidikan Nasional

Malik, A. (2014). Kompetensi Pedagogis Guru dalam Konteks Implementasi Kurikulum 2013. http://repository.ut.ac.id/id/eprint/1398.

Moh. Suardi, S. (2012). Pengantar Pendidikan. Jakarta Barat: Indeks.

Putri, A. D. K., \& Imaniyati, N. (2017). Pengembangan Profesi Guru Dalam Meningkatkan Kinerja Guru. Jurnal Pendidikan Manajemen Perkantoran, 1(1), 94-103.

Rugaiyah, M. ,. (2011). Profesi Kependidikan . Bogor: Ghalia Indonesia.

Rusman, M. (2011). Manajemen Kurikullum. Jakarta: PT. RajaGrafindo Persada.

Sugiyono, P. D. (2017). Metode Penelitian. Bandung: Alfabeta.

Syaiful Bahri Djamarah, M. (2014). Guru dan Anak DIdik Dalam interaksi Edukatif. Jakarta: PT Asdi Mahasatya.

Syaiful Sagala, M. (2013). Kemampuan Profesional Guru Dan Tenaga Pendidikan. Bandung: Alfabeta.

Triwiyanto, T. (2014). Pengantar Pendidikan. Jakarta: PT Bumi Aksara.

Wina Sanjaya, M. (2010). Kurikulum dan Pembelajaran. Jakarta: kencana. 
Yusutria, M. A. (2017). Profesionalisme Guru Dalam Meningkatkan Kualitas Sumber Daya Manusia. Curricula: Journal of Teaching and Learning, 2(1). 